Огляди літератури, оригінальні дослідження, погляд на проблему

УДК 616.379.2+616.441-008.61]-08-02:612.015.32

DOI 10.11603/1811-2471.2016.v0.i4.7077

\title{
ВИВЧЕННЯ ЕФЕКТИВНОСТІ ДІЇ ІНСУЛІНОВИХ СЕНСИТАЙЗЕРІВ НА ВУГЛЕВОДНИЙ ТА ЛІПІДНИЙ ОБМІН У ХВОРИХ З ДИФУЗНИМ ТОКСИЧНИМ ЗОБОМ ТА ІНСУЛІНОРЕЗИСТЕНТНІСТЮ
}

\author{
๑О. П. Кіхтяк, О. З. Ліщук, Х. А. Москва \\ Львівський національний медичний університет імені Данила Галицького
}

\begin{abstract}
РЕЗЮМЕ. Наукові роботи останніх років звертають увагу на знижену чутливість до інсуліну в хворих із функціональною тиреоїдною патологією як при гіпо-, так і при гіпертиреозі. В результаті проведеного дослідження виявлено сприятливий вплив додаткового призначення інсулінових сенситайзерів хворим з дифузним токсичним зобом і наявною інсулінорезистентністю на показники вуглеводного та ліпідного обміну, а також позитивний ефект на тиреоїдну функцію. Отримані результати свідчать про тісний зв'язок між рівнем тиреоїдних гормонів і глюкозним метаболізмом.

КЛЮчОВІ СЛОВА: дифузний токсичний зоб, інсулінорезистентність, тирозол, метформін, піоглітазон.
\end{abstract}

Вступ. Тиреоїдні гормони відіграють важливу роль у регуляції метаболізму глюкози та ліпідів. Уперше тісний зв'язок гормонів щитоподібної залози та вуглеводного обміну детально описав лауреат Нобелівської премії доктор Бернардо Альберто Хуссей в 1947 році. Відтоді з'ясували, що гіпертиреоз асоціюється з інсулінорезстентністю (IP) $[5,8]$. Наукові роботи останніх років звертають увагу на знижену чутливість до інсуліну загалом в усіх хворих із функціональною тиреоїдною патологією, як при гіпо-, так і при гіпертиреозі [11]. Як випливає з даних літератури, переважна кількість тиреоїдозалежних генів знаходяться саме в печінці, яка безпосередньо відповідає за процес глюконеогенезу та метаболізм глікогену $[9,12,19]$. Встановлення наявності IP при підвищеній функції щитоподібної залози спонукало до пошуку засобів їі корекції.

До медикаментів, які зменшують IP, відносять метформін (група бігуанідів) і піоглітазон (група тіазолідиндіонів). Метформін - єдиний представник своєї групи, що визнаний усіма діабетичними та ендокринологічними асоціаціями у світі, зокрема Американською діабетичною асоціацією (American Diabetes Association - ADA), Європейською асоціацією з вивчення діабету (European Association for the Study of Diabetes - EASD) [7]. Метформін застосовують у лікуванні пацієнтів із цукровим діабетом 2-го типу та для його профілактики на стадії предіабету, синдромі полікістозних яєчників, ожирінні, неалкогольному жировому стеатозі печінки. Метформін підвищує чутливість до ендогенного інсуліну, знижує глюконеогенез, впливає на ліпідний метаболізм, а також має тиреопротективну властивість $[5,13]$. Піоглітазон - агоніст $ү$-рецепторів, що активуються пероксисомним проліфератором (PPAR-ү), які разом з рецепторами до тиреоїдних гормонів відносяться до однієї суперсім'ї ядерних рецепторів. Експериментально встановлено, що інтрацеребральне введення PPAR-ү агоніста піоглітазону змі- нювало транскрипцію тиреотропін-рилізингового гормону в гіпоталамусі та знижувало вміст вільного тироксину $[3,11]$. Вдалося виявити, що піоглітазон знижує показники IP через пригнічення рівня фактора некрозу пухлин-а у хворих на дифузний токсичний зоб (ДТЗ) [10]. Як відомо, фактор некрозу пухлин-апорушуєсигнальнийфосфатидилінозитол3-кіназний шлях, якому належить провідна роль щодо ефектів інсуліну та його перехресної взаємодії з тиреоїдними гормонами. Нездатність інсуліну працювати через цей шлях назвали IP ендотелію [6, 15]. 3'ясували також позитивний вплив піоглітазону на гальмування розвитку офтальмопатій при дтЗ [14].

Мета дослідження - з'ясувати як призначення піоглітазону та метформіну впливатиме на показники тиреоїдних гормонів, ліпідний та вуглеводний обмін у хворих з дифузним токсичним зобом та наявною інсулінорезистентністю.

Матеріал і методи дослідження. У дослідження залучили 48 хворих на ДТЗ, середній вік яких становив 40,3 року, з них 36 жінок і 10 чоловіків. Пацієнтів, яких відібрали в дослідження, поділили на три групи. Кількість хворих на ДТЗ розподілили таким чином: у першу групу ввійшло 14 хворих (10 жінок, 4 чоловіки), у другу групу - 18 осіб (12 жінок, 4 чоловіки), у третю групу - 16 пацієнтів (14 жінок, 2 чоловіки).

Відбір хворих відбувався під час амбулаторного прийому у Львівському обласному державному клінічному лікувально-діагностичному ендокринологічному центрі, а також після консультацій на кафедрі ендокринології Львівського національного медичного університету імені Данила Галицького. Діагноз ДТЗ було верифіковано у відповідності до “Стандартів діагностики та лікування ендокринних захворювань" [4]. Обрані пацієнти з ДТЗ не мали значущої супутньої патології і раніше не отримували жодного лікування з приводу ураження щитоподібної залози. 
Огляди літератури, оригінальні дослідження, погляд на проблему

Після обстеження всім хворим з метою досягнення еутиреозу призначали тирозол, доза якого підбиралась індивідуально і коливалась у межах від 5 до 30 мг на добу. Наступні три місяці хворі першої групи продовжили отримувати тирозол, у другій - до тирозолу додали метформін (1000 мг на добу), у третій - тирозол комбінували з піоглітазоном, дозування якого коливалося відповідно до необхідності (від 15 мг до 30 мг на добу). Після закінчення другого етапу лікування та отримання завершальних даних здійснили статистичний аналіз результатів.

Функціональний стан щитоподібної залози оцінювали за допомогою визначення базальних концентрацій тиреотропного гормону гіпофіза (ТТГ), вільного тироксину (вТ4) та вільного трийодтироніну (вТ3) у сироватці венозної крові хворих імуноферментним методом за допомогою тест-системи компанії Roche Diagnostics (Щвейцарія) на автоматичному аналізаторі Cobas 6000 (е 601 модуль).

Вміст глюкози у крові визначали за допомогою гексокіназного методу, рівень глікозильованого гемоглобіну (HbA1c) - імунотурбідиметричним методом, концентрацію загального холестерину (XC) - ферментно-спектрофотометричним методом, активність аланінамінотрансферази (АлАТ) за допомогою кінетичного методу на аналізаторі Cobas 6000 (с 501 модуль). Кількісне визначення імунореактивного інсуліну в сироватці венозної крові проводили за допомогою аналізатора Cobas 6000 (е 601 модуль) з використанням тест-системи Roche Diagnostics (Швейцарія), в основі якого лежить імунохімічний метод з електрохемілюмінесцентною детекцією (ECLIA). Для визначення С-пептиду застосовували двоступінчастий хемілюмінесцентний імуноаналіз (CLIA) 3 використанням аналізатора Liaison і тест-смужок до нього DiaSorin (Італія). HOMA-індекс інсуліно- резистентності (HOMA-IR) обчислювали за формулою: глюкоза натще (ммоль/л) х інсулін натще (мкMO/мл) / 22,5. Показник HOMA-IR в нормі не перевищує 2,77.

Статистичне опрацювання результатів здійснювали за допомогою програмного забезпечення "Microsoft Excel" (США) та "STATISTICA" 6,0 ("Statsoft", США), що ґрунтувалось на літературних джерелах [1]. Вірогідність відмінностей оцінювали за t-критерієм (критерій Стьюдента). Різницю параметрів вважали статистично значущою за $\mathrm{p}<0,05$.

Результати й обговорення. За нашими даними, у першій групі після шестимісячного лікування тирозолом вдалося внормувати показники ТТГ, які підвищилися з високою вірогідністю від $(0,015 \pm 0,04)$ до $(2,43 \pm 0,15)$ мкМО/мл $(p<0,001)$. Зниження рівня гормонів щитоподібної залози також було вірогідним $(p<0,001)$, оскільки вТ ${ }_{4}$ на початку дослідження визначався на рівні $(3,19 \pm 0,30)$ нг/дл, а згодом зменшився до $(1,55 \pm 0,04)$ нг/дл відповідно. Виявили також високовірогідне зниження вТ до значень $(3,31 \pm 0,12)$ пг/мл на тлі лікування тирозолом $(p<0,001)$.

Зміна лабораторних показників вуглеводного та ліпідного обміну до і після шести місяців лікування тирозолом хворих на ДТЗ першої групи відображено в таблиці 1.

Нами не зафіксовано жодних вірогідних змін за даними інших показників, що досліджувалися, після шести місяців тиреостатичної терапії.

Додаткове призначення метформіну (табл. 2) у другій групі хворих на ДТЗ вплинуло на вуглеводний обмін і характеризувалось вірогідним зниженням HbA1c, з $(5,12 \pm 0,07) \%$ до $(4,89 \pm 0,06) \%$ $(p<0,05)$, та вірогідним зниженням концентрації глюкози натще $(5,19 \pm 0,10)$ ммоль/л $(p<0,05)$ у порівнянні з результатами, отриманими до лікуван-

Таблиця 1. Зміни показників тиреоїдних гормонів, вуглеводного та ліпідного обміну до і після шестимісячного лікування на тлі монотерапії тирозолом хворих на ДТЗ першої групи

\begin{tabular}{|l|c|c|c|}
\hline \multicolumn{1}{|c|}{ Показники } & Референтні значення & $\begin{array}{c}\text { До лікування } \\
(\mathrm{M} \pm \mathrm{m}, \mathrm{n}=23)\end{array}$ & $\begin{array}{c}\text { На тлі лікування тирозолом } \\
(\mathrm{M} \pm \mathrm{m}, \mathrm{n}=23)\end{array}$ \\
\hline ВТ4 (нг/дл) & $0,93-1,7$ & $3,19 \pm 0,30$ & $1,55 \pm 0,04^{*}$ \\
\hline ВТ3 (пг/мл) & $2,5-4,3$ & $17,12 \pm 1,42$ & $3,31 \pm 0,12^{*}$ \\
\hline ТТГ (мкМО/мл) & $0,27-4,2$ & $0,015 \pm 0,04$ & $2,43 \pm 0,15^{*}$ \\
\hline Глюкоза (ммоль/л) & $4,11-6,05$ & $5,61 \pm 0,11$ & $5,55 \pm 0,09$ \\
\hline НЬА1с (\%) & $4,8-5,9$ & $5,21 \pm 0,07$ & $5,16 \pm 0,07$ \\
\hline Інсулін (мкМО/мл) & $2,6-24,9$ & $13,41 \pm 0,55$ & $12,01 \pm 0,55$ \\
\hline НОМА-ІR (ум.од) & $<2,77$ & $3,26 \pm 0,18$ & $2,91 \pm 0,16$ \\
\hline ХС (ммоль/л) & $<5,2$ & $3,94 \pm 0,13$ & $4,23 \pm 0,13$ \\
\hline АлАТ (МО/л) & $<41,0-$ жін. & $29,84 \pm 1,78$ & $28,93 \pm 1,38$ \\
\hline
\end{tabular}

Примітка. * - вірогідність відмінності у порівнянні з показниками до лікування $p<0,05$. 
Огляди літератури, оригінальні дослідження, погляд на проблему

Таблиця 2. Зміна показників тиреоїдних гормонів, вуглеводного та ліпідного обміну до і після шестимісячної комбінованої терапії тирозолом з метформіном

\begin{tabular}{|l|c|c|c|}
\hline \multicolumn{1}{|c|}{ Показники } & Референтні значення & $\begin{array}{c}\text { До лікування } \\
(\mathrm{M} \pm \mathrm{m}, \mathrm{n}=26)\end{array}$ & $\begin{array}{c}\text { На тлі комбінованої терапії тирозол + } \\
\text { метформін }(\mathrm{M} \pm \mathrm{m}, \mathrm{n}=26)\end{array}$ \\
\hline ВТ4 (нг/дл) & $0,93-1,7$ & $4,38 \pm 0,35$ & $1,57 \pm 0,05^{*}$ \\
\hline ВТ3 (пг/мл) & $2,5-4,3$ & $16,24 \pm 1,07$ & $3,28 \pm 0,10^{*}$ \\
\hline ТТГ (мкМО/мл) & $0,27-4,2$ & $0,016 \pm 0,04$ & $2,88 \pm 0,16^{*}$ \\
\hline Глюкоза (ммоль/л) & $4,11-6,05$ & $5,84 \pm 0,08$ & $5,19 \pm 0,10^{*}$ \\
\hline НЬА1с (\%) & $4,8-5,9$ & $5,12 \pm 0,07$ & $4,89 \pm 0,06^{*}$ \\
\hline Інсулін (мкМО/мл) & $2,6-24,9$ & $12,94 \pm 0,50$ & $2,73 \pm 0,12^{*}$ \\
\hline НОМА-ІR (ум.од) & $<2,77$ & $3,34 \pm 0,16$ & $4,28 \pm 0,12^{*}$ \\
\hline ХС (ммоль/л) & $<5,2$ & $3,84 \pm 0,11$ & $28,70 \pm 1,04$ \\
\hline АлАТ (МО/л) & $<41,0-$ жін. & $31,94 \pm 1,82$ & \\
\hline
\end{tabular}

Примітки. 1. * - вірогідність відмінності у порівнянні з показниками до лікування р<0,05;

2. \# - тенденція вірогідних змін у порівнянні з показниками до лікування 0,05<p<0,1.

ня $((5,84 \pm 0,08)$ ммоль/л). Відмітили тенденцію вірогідних змін за даними рівня інсуліну, який до лікування становив $(12,94 \pm 0,50)$ мкМО/мл, а після комбінованого лікування тирозолом з метформіном досяг значень $(11,72 \pm 0,36)$ мкМО/мл $(0,05<p<0,1)$. Зафіксовано вірогідні зміни за даними індексу HOMA-IR, який зменшився до $(2,73 \pm 0,12)$ ум.од від рівня $(3,34 \pm 0,16)$ ум.од $(p<0,05)$. Цей ефект можемо пояснити додатковим призначенням метформіну, який не лише знижував концентрацію глюкози натще, але й позитивно впливав на індекс НОМА. Як бачимо, зміна вуглеводного обміну була вірогідною лише після лікування метформіном, що збігається з даними інших науковців [97].

Разом із поліпшенням показників вуглеводного обміну та зменшенням інсулінорезистентності на тлі комплексного лікування метформіном і тирозолом відбулося вірогідне покращення показників ліпідного обміну, а саме зміна рівня
ХС до $(4,28 \pm 0,12)$ ммоль/л після комбінованого лікування, порівняно зі значенням $(3,84 \pm 0,11)$ ммоль/л до початку лікування $(p<0,05)$. Зазначимо, що низка авторів описують порушення ліпідного обміну хворих на ДТЗ як зниження показників ХС і ЛПНЩ [16]. Нами також підтверджено наявність такої картини змін. Отже, підвищення рівня XC у результаті комбінованої терапії відображає позитивну динаміку лікування пацієнтів 3 даною патологією. Також слід зазначити, що підвищення показників ліпідного обміну не перевищувало референтних меж та знаходилося на рівні своїх оптимальних значень. Під час застосування метформіну з тирозолом у хворих на ДТЗ та IP не спостерігалося статистично значущих змін активності АлАТ.

У результаті поєднаного призначення тирозолу й піоглітазону після другого етапу дослідження в третій групі (табл. 3) виявили низку вірогідних відмінностей. Додаткове призначення піоглі-

Таблиця 3. Зміна показників тиреоїдних гормонів, вуглеводного та ліпідного обміну до і після шестимісячної комбінованої терапії тирозолом і піоглітазоном

\begin{tabular}{|l|c|c|c|}
\hline \multicolumn{1}{|c|}{ Показники } & Референтні значення & $\begin{array}{c}\text { До лікування } \\
(\mathrm{M} \pm \mathrm{m}, \mathrm{n}=22)\end{array}$ & $\begin{array}{c}\text { На тлі комбінованої терапії } \\
\text { тирозол + піоглітазон } \\
(\mathrm{M} \pm \mathrm{m}, \mathrm{n}=22)\end{array}$ \\
\hline ВТ4 (нг/дл) & $0,93-1,7$ & $4,49 \pm 0,43$ & $1,58 \pm 0,06^{*}$ \\
\hline ВТ3 (пг/мл) & $2,5-4,3$ & $16,84 \pm 1,00$ & $3,41 \pm 0,11^{*}$ \\
\hline ТТГ (мкМО/мл) & $0,27-4,2$ & $0,021 \pm 0,005$ & $2,41 \pm 0,17^{*}$ \\
\hline Глюкоза (ммоль/л) & $4,11-6,05$ & $5,71 \pm 0,08$ & $5,61 \pm 0,05^{*}$ \\
\hline НЬА1с (\%) & $4,8-5,9$ & $5,17 \pm 0,09$ & $5,12 \pm 0,06$ \\
\hline Інсулін (мкМО/мл) & $2,6-24,9$ & $13,22 \pm 0,34$ & $11,53 \pm 0,23^{*}$ \\
\hline НОМА-ІR (ум.од) & $<2,77$ & $3,41 \pm 0,12$ & $2,88 \pm 0,08^{*}$ \\
\hline ХС (ммоль/л) & $<5,2$ & $4,11 \pm 0,13$ & $4,34 \pm 0,13$ \\
\hline АлАТ (МО/л) & $<41,0-$ жін. & $31,77 \pm 1,72$ & $24,98 \pm 1,11^{*}$ \\
\hline
\end{tabular}

Примітка. * - вірогідність відмінності у порівнянні з показниками до лікування $p<0,05$; 
Огляди літератури, оригінальні дослідження, погляд на проблему

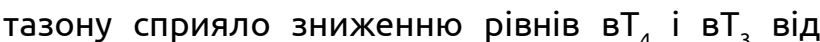
$(4,49 \pm 0,43)$ нг/дл до $(1,58 \pm 0,06)$ нг/дл $(p<0,05)$, і від $(16,84 \pm 1,00)$ пг/мл до $(3,41 \pm 0,11)$ пг/мл $(p<0,05)$ відповідно та підвищенню концентрації ТТГ від $(0,021 \pm 0,005)$ до $(2,41 \pm 0,17)$ мкМО/мл $(p<0,05)$. Наші спостереження збігаються з даними інших дослідників у тому, що на фоні призначення піоглітазону знижується вільний тироксин. Припускають, що цей ефект виникає завдяки підвищенню чутливості до ТТГ у залозі $[15,18]$.

Унаслідок сумації впливів тирозолу і піоглітазону вдалося домогтися вірогідного зниження глюкози в крові, від $(5,71 \pm 0,08)$ до $(5,61 \pm 0,05)$ ммоль/л $(p<0,05)$. Водночас зафіксовано відсутність зміни за даними НbА1с упродовж шести місяців терапії, що, ймовірно, пов'язано з недостатньою тривалістю спостереження для даного випадку, оскільки зміна рівня глюкози в крові була незначною і знаходилась в межах референтних значень, оскільки цей показник має пряму кореляцію з рівнем глюкози крові. Концентрація інсуліну вірогідно знизилась на фоні комбінованого лікування від $(13,22 \pm 0,34)$ мкМО/мл до $(11,53 \pm 0,23)$ мкМО/мл відповідно. Встановили вірогідну зміну за даними індексу HOMA-IR, який зменшився до $(2,88 \pm 0,08)$ ум. од з $(3,41 \pm 0,12)$ ум.од $(p<0,05)$. Слід зауважити, що індекс HOMA-IR досяг вірогідної зміни унаслідок зниження рівня інсуліну. У нашому дослідженні не було зафіксовано достовірних вірогідних змін показників ліпідного обміну після комбінованої терапії тирозолом з піоглітазоном у хворих на ДТЗ.

Ми виявили вірогідну зміну активності АлАТ від $(31,77 \pm 1,72)$ МО/л до $(24,98 \pm 1,11)$ МО/л на тлі комбінованого лікування тирозолом і піоглітазоном $(p<0,05)$. Отримані результати збігаються 3 даними багатоцентрового рандомізованого конт-

\section{ЛІТЕРАТУРА}

1. Боровиков В. STATISTICA: Искусство анализа данных на компьютере. Для профессионалов / В. Боровиков. - СПб. : Питер, 2001. - 656 с.

2. Ліщук О. 3. Аналіз результатів застосування PPAR- $\vee$ агоніста піоглітазону у хворих на дифузний токсичний 306 та інсулінорезистентність / О. 3. Ліщук, О. П. Кіхтяк, Х. А. Москва // East European Scientific Journal. - 2016. - Vol. 2, N 10. - P. 40-43.

3. Москва Х. А. Вплив інсулінових сенситайзерів на ліпідний і вуглеводний обмін у хворих з гіпотиреозом та інсулінорезистентністю / Х. А. Москва, Л. Є. Лаповець, О. П. Кіхтяк // Acta Medica Leopoliensia. - 2013. № 3. - C. $15-20$.

4. Протоколи надання медичної допомоги хворим із патологією ендокринної системи / Український науково-практичний центр ендокринної хірургії, трансплантації ендокринних органів і тканин МОЗ України. - K. : 2011. - 110 c. рольованого дослідження PIVENS, яке включало пацієнтів з неалкогольною жировою гепатопатією без цукрового діабету, що отримували піоглітазон. У спостереженні зафіксували зменшення вираженості стеатозу печінки та її запальних змін з покращенням резистентності до інсуліну і зниженням печінкових трансаміназ [18].

Висновки. 1. У результаті проведеного лікування в обстежених групах пацієнтів з дифузним токсичним зобом та інсулінорезистентністю вдалося домогтися еутиреозу за даними рівня тиреотропного гормону, вільного тироксину та вільного трийодтироніну.

2. Застосування метформіну в комбінації з тирозолом у хворих з дифузним токсичним зобом вірогідно поліпшує показники вуглеводного й ліпідного обміну, знижує гіперінсулінемію й супутню інсулінорезистентність.

3. Завдяки комбінованому лікуванню хворих із використанням піоглітазону та тирозолу виявлено зменшення, у порівнянні до початкового рівня, таких показників, як інсулін, глюкоза крові натще, індекс HOMA-IR. Виявлено також зниження активності аланінамінотрансферази, що віддзеркалює рівень печінкової інсулінорезистентності.

4. Під час призначення інсулінових сенситайзерів (метформіну й піоглітазону) хворим на дифузний токсичний зоб із встановленою інсулінорезистентністю виявлено позитивний вплив на вуглеводний та ліпідний обмін, а також сприятливий ефект на тиреоїдну функцію, що ще раз підтверджує зв'язок між гомеостазом тиреоїдних гормонів і глюкозним метаболізмом.

Перспективою подальших досліджень у цьому напрямку є уточнення досі невідомих патогенетичних механізмів розвитку інсулінорезистентності при дифузному токсичному зобі.

5. Скибчик В. А. Інсулінорезистентність: клінічне значення, методивизначення, підходидо лікування/В.А.Скибчик // Укр. мед. часопис. - 2006. - № 6 (56). - С. 61-67.

6. Центральні важелі розвитку периферійної інсулінорезистентності / О. П. Кіхтяк, Ю. Г. Орел, Н.В.Скрипник, Х. А. Москва // Клінічна ендокринологія та ендокринна хірургія. - 2012. - № 2. - С. 16-18.

7. American Association of Clinical Endocrinologists' comprehensive diabetes management algorithm consensus statement / A. J. Garber, M. J. Abrahamson, J. I. Barzilay [et al.] // Endocr. Pract. - 2013. - Vol. 19, No. 2. - P. 536-557.

8. Brenta G. Why can insulin resistance be a natural consequence of thyroid dysfunction? / G. Brenta // J. Thyroid. Res. - 2011. - Vol. 3. - P. 129-138.

9. Crunkhorn S. Links between thyroid hormone action, oxidative metabolism, and diabetes risk? / S. Crunkhorn, M. E. Patti // Thyroid. - 2008. - Vol. 18, No. 2. - P. 227-237. 
Огляди літератури, оригінальні дослідження, погляд на проблему

10. Cytokines (interferon- $y$ and tumor necrosis factora)-induced nuclear factor-kB activation and chemokine (C-X-C motif) ligand 10 release in Graves disease and ophthalmopathy are modulated by pioglitazone / A. Antonelli, S. M. Ferrari, P. Fallahi [et al.] // Metabolism. 2011. - Vol. 2. - P. 227-283.

11. Glycemic status in hyperthyroid subjects / D. T. Paul, F. H. Mollah, M. K Alam [et al.] // Mymensingh Med. J. - 2004. - Vol. 13 (1). - P. 71-75.

12. Jahagirdar $\mathrm{V}$. Thyroid hormone's role in regulating brain glucose metabolism and potentially modulating hippocampal cognitive processes / V. Jahagirdar, E. C. McNay // Metab. Brain. Dis. - 2012. - Vol. 27, No. 2. - P. 101-111.

13. Kalra S. Metformin: midlife maturity, maiden charm/S. Kalra, P. Dhamija, A. K. Das //Indian. J. Endocrinol. Metab. - 2012. - Vol. 16, No. 6. - P. 1015-1018.

14. Monokine induced by interferon (IFN) (CXCL9) and IFN inducible T-Cell-Chemoattractant (CXCL11) involvement in Graves' disease and ophthalmopathy:

modulation by peroxisome proliferator-activated receptor - agonists / A. Antonelli, S. M. Ferrari, P. Fallahi [et al.] // Journal of Clinical Endocrinology and Metabolism. - 2009. - Vol. 94 (5). - P. 1803-1809.

15. Muniyappa R. Insulin action and insulin resistance in vascular endothelium / R. Muniyappa, M. Quon // Curr. Opin. Clin. Nutr. Metab. Care. - 2007. No. 32 (10). - P. 523-530.

16. Peroxisome proliferator-activated receptor-gammamediated positive energy balance in the rat is associated with reduced sympathetic drive to adipose tissues and thyroid status / W. T. Festuccia, S. Oztezcan, M. Laplante [et al.] // Endocrinology. - 2008. - Vol. 149, No. 5. - P. 2121-2130.

17. Pioglitazone, vitamin $\mathrm{E}$, or placebo for nonalcoholic steatohepatitis / A. J. Sanyal, N. Chalasani, K. V. Kowdley [et al.] // N. Engl. J. Med. - 2010. - Vol. 362. - P. 1675-1685.

18. Skeletal muscle insulin resistance in endocrine disease / M. Peppa, Ch. Koliaki, P. Nikolopoulos [et al.] // J. Biomed. Biotechnol. - 2010. - Vol. 1. - P. 200-213.

\title{
STUDYING OF THE BENEFICIAL EFFECT OF INSULIN SENSITIZER ON THE CARBOHYDRATE AND LIPID METABOLISM IN PATIENTS WITH DIFFUSE TOXIC GOITRE AND INSULIN RESISTANCE
}

\author{
๑O. P. Kikhtyak, O. Z. Lishchuk, Kh. A. Moskva \\ Danylo Halytskyi Lviv National Medical University
}

SUMMARY. Recent studies have been focused on the decreased insulin sensitivity in patients with functional thyroid disorders in both hypo- and hyperthyroidism. The study has detected the positive influence of additionally prescribed insulin sensitizers to patients with diffuse toxic goitre and present insulin resistance to carbohydrate and lipid metabolism markers, as well as beneficial effect on thyroid function.

KEY WORDS: diffuse toxic goiter, insulin resistance, thyrozol, metformin, pioglitazone. 